\title{
Comparison of electrophoretic and meristic characters of 0-group eel larvae from the Sargasso Sea
}

\author{
A. Comparini ${ }^{1} \&$ M. Schoth ${ }^{2}$ \\ ${ }^{1}$ Institute of Animal Biology, University of Padua; Via Loredan 10, I-35100 Padua, Italy \\ ${ }^{2}$ Biologische Anstalt Helgoland (Zentrale); Notkestraße 31, D-2000 Hamburg 52, \\ Federal Republic of Germany
}

\begin{abstract}
Marked differences between continental samples of American and European eels have been detected electrophoretically in allele frequencies at the MDH-2 locus. Starch gel electrophoresis carried out on board F. R. V. "Anton Dohrn" during the eel expedition to the Sargasso Sea in 1979 revealed a similar clear-cut genetic difference in a sample of 0-group Anguilla leptocephali, thus confirming the classical theory of Schmidt (1932). The MDH-2 genotypes provide an additional diagnostic character for the distinction between young $A$. anguilla and $A$. rostrata leptocephali. Species identification by biochemical genetic characters did not correspond with that by meristic characters (myomere numbers) in ca. $13 \%$ of the specimens studied; this discrepancy mainly concerns leptocephali of the $A$. anguilla genotype. The results obtained are critically discussed.
\end{abstract}

\section{INTRODUCTION}

An additional tool for the solution of taxonomic problems has been provided by the introduction of biochemical methods, particularly by enzyme electrophoresis on starch and acrylamide gels (Rollinson, 1980). This technique (Brewer, 1970; Ayala \& Valentine, 1978 ) reveals the variants of a protein, the product of a specific gene locus, by differential electrophoretic mobilities. Provided a reliable genetic interpretation can be given to explain the pattern of electrophoretic variation of a particular enzyme (Utter et al., 1974; Allendorf \& Utter, 1979), the study of allelic variants (allozymes) may provide useful information about the genetic structure of natural populations in space and time.

The utilization of electrophoretic variants of enzymes as genetic markers was useful in two areas of ichthyological research: (1) the marking of populations or stocks of economically important species to identify their course of migration and different breeding grounds; (2) the study of interspecific differences for the solution of taxonomic problems (De Ligny, 1971, 1972; Rodinó \& Comparini, 1978b). Allozymes as genetic tags are in fact more reliable tools for this kind of investigations than traditionally used morphometric and meristic characters (Avise, 1975).

Electrophoretic methods have significantly contributed to the solution of controversies regarding the classical theory of Schmidt (1932) on the origin of Atlantic and Mediterranean eel (Rodinó \& Comparini, 1978a, b). In particular, Tucker's (1959) controversial view on the existence of two different ecophenotypes of a single Atlantic eel species has been strongly challenged. Sick et al. (1967) demonstrated hemoglobin 
polymorphism in the American eel, while the European eel is monomorphic; Jamieson \& Turner (1980) reported differences between the two Atlantic populations in muscle proteins. A significant contribution at the genetic level was the elucidation of marked differences in allele frequencies of the MDH-2 locus (malate dehydrogenase) between samples of American and European eels observed by De Ligny \& Pantelouris (1973) and confirmed by Williams et al. (1973) and Rodinó \& Comparini (1978a).

This biochemical genetic difference was, however, observed at advanced developmental stages; it could result from differential selection, depending on different environmental conditions met with by leptocephali during their migration to different continental waters. Indeed, caution is due when inferring reproductive isolation from the genetic differentiation observed in elvers and more advanced stages of eels (Koehn \& Williams, 1978).

Therefore, conclusive evidence proving the presence of two separate gene pools in Atlantic eels could be obtained from the analysis of samples of young leptocephali caught in or in the vicinity of the breeding area. This opportunity was offered by the 1979 eel expedition of the F.R.V. "Anton Dohrn" to the Sargasso Sea.

During the cruise, eel larvae were analysed for some enzymes (see Comparini \& Rodinó, 1980). Particular attention from the taxonomic point of view was given to $\mathrm{MDH}$ electrophoretic patterns because of the above reported differences in allele frequencies between the two continental populations. Proving the existence of a similar, clear-cut genetic difference between two distinct larval pools in the breeding area, besides confirming Schmidt's theory, provided an additional or confirmative diagnostic character for the identification of both eel species at the larval stage.

In this paper, data on genetic variability in eel larval samples made available by the study of the $\mathrm{MDH}$ locus are reported. Moreover, the results attained after comparison of the 2 methods of species identification, by biochemical genetic and meristic characters, are given. The data are discussed with particular reference to taxonomic studies, based on myomere counts of 0-group Anguilla larvae (Schoth, 1982).

\section{MATERIALS AND METHODS}

Figure 1 shows the route of the F. R. V. "Anton Dohrn" and the different haul stations for eel larvae collection. Details of the 1979 eel expedition, the fishing equipment and other technique data are reported mainly by Tesch et al. (1979) and Tesch (1982); more information about the place of capture, number and distribution of the 0-group Anguilla larvae are given by Schoth \& Tesch (1982).

Anguilla leptocephali can easily be distinguished from those of other Anguilliformes (Smith, 1979). Immediately after the different hauls, Anguilla larvae were roughly sorted out on board; the rest were identified from the preserved ichthyoplankton in the laboratory where the main myomere countings were carried out (for further details, see Schoth, 1982).

Out of more than 2,000 leptocephali (mainly the 0-group) separated on board, 121 individuals of the 0-group (7-25 $\mathrm{mm}$ in length) and five of the I-group (about $40 \mathrm{~mm}$ ) were analysed by electrophoresis on board. The number of leptocephali electrophoresed at the different stations (all from the first part of the cruise) is given in Figure 1. The five I-group specimens derived from the fourth haul, which was taken in the middle of the 


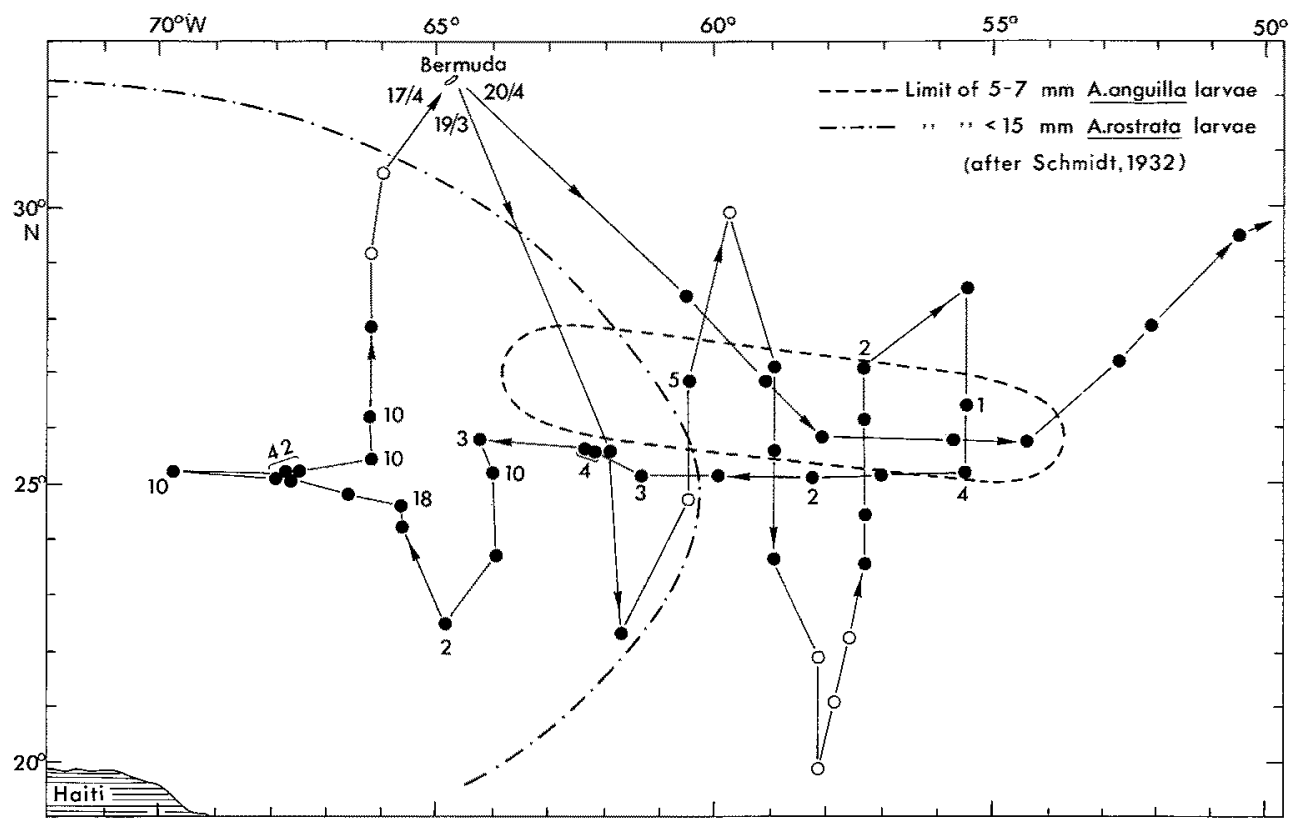

Fig. 1. Route of F. R. V. "Anton Dohrn" with positive - and negative o hauls of 0-group Anguilla leptocephali. Number of leptocephali used for electrophoresis at each haul station

Anguilla anguilla hatching area. Prior to electrophoretic treatment, the body length of all specimens was measured and the myomeres of the majority of the analysed 0 -group leptocephali caught west of $61^{\circ} \mathrm{W}$ were counted.

If possible, leptocephali were immediately electrophoresed; otherwise they were frozen $\left(-30^{\circ} \mathrm{C}\right)$ and used within a few hours. Apart from the appearance of a supplementary electrophoretic band (see below and Comparini \& Rodinó, 1980), no important differences were discovered between frozen and fresh specimens. Horizontal electrophoresis was performed in $11.5 \%$ starch gel ("Biotestgel", Biotest-Serum Inst. GmbH, Frankfurt/M.), using an apparatus similar to that described by Ayala \& Valentine (1978). Whole leptocephali or cephalic halves of their bodies were carefully washed in an icecold $1 \% \mathrm{NaCl}$ solution. Each individual sample was put into a micro-tube, then finely minced with scissors in 2 to 3 volumes of $0.05 \mathrm{M}$ Tris- $\mathrm{HCl}, \mathrm{pH} 7.2$, at $4{ }^{\circ} \mathrm{C}$. With the help of tweezers, a little rectangle $(5 \times 6 \mathrm{~mm})$ of chromatography paper was put into each of the tubes and soaked with homogenate. Finally, each soaked paper was deposed into the sample slot of the gel. Electrophoretic conditions and $\mathrm{MDH}$-staining method are reported elsewhere (Comparini et al., 1975; Comparini \& Rodinó، 1980).

\section{RESULTS}

MDH-2 genotype distribution in the Anguilla larval sample

The MDH electrophoretic patterns of Anguilla larvae analysed on board (Fig. 2) correspond to those described in elvers and older eels of $A$. anguilla (Comparini et al., 


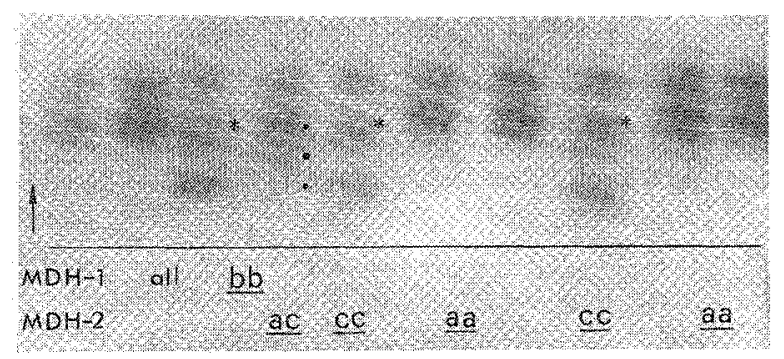

Fig. 2. Photograph of MDH electrophoretic patterns observed in the Anguilla leptocephali sample. Corresponding genotypes (according to Fig. 3) are also reported. Asterisks indicate the position of bands which appear in frozen specimens due to mitochondrial MDH activity

1975 and Comparini \& Rodinó, 1980) and A. rostrata (Williams et al., 1973). As in other teleosts, MDH is controlled by two gene loci, one of them (MDH-1) ist almost monomorphic while the other (MDH-2) is polymorphic in the two Anguilla species studied.

Figure 3 shows schematically the $\mathrm{MDH}$ patterns observed in the leptocephali sample together with their genetic interpretation (for further details see Comparini et al, 1975; Comparini \& Rodinó, 1980). As in continental samples, a very low variability was observed for MDH-1 (two heterozygotes, $a b_{r}$ were observed), while MDH-2 was polymorphic in the larval sample also. The observed and expected genotype distribution (according to the Hardy-Weinberglaw), as well as the allele frequencies for the MDH-2 locus are reported in Table 1a. The allele frequencies are different from those reported in the continental eel samples of both populations (Comparini \& Rodinó, 1980). The observed genotype distribution shows a highly significant difference $\left(x^{2}(3)=78.3, \mathrm{P} \ll\right.$ $0.01)$, due to a strong excess of homozygotes compared with the expected values for a single panmictic population.

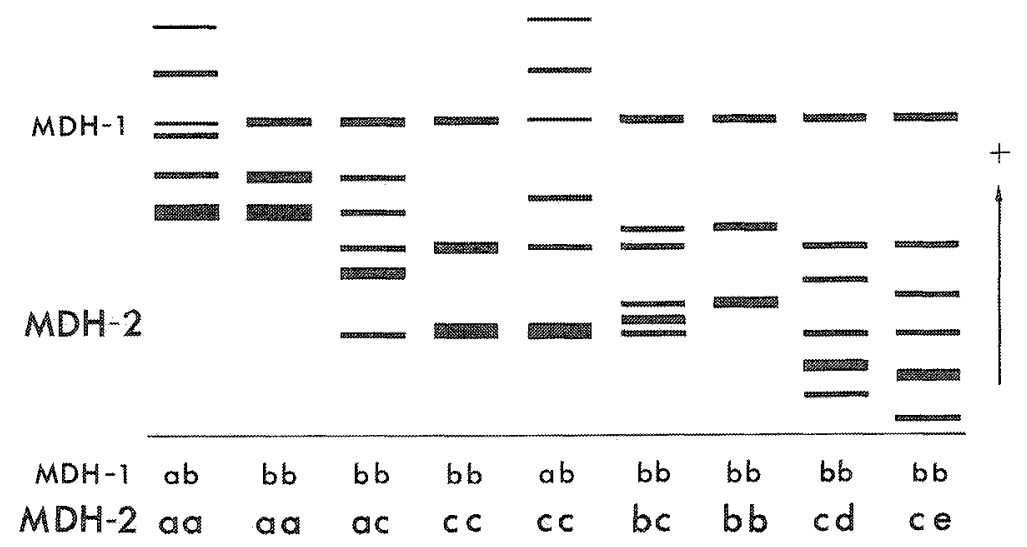

Fig. 3. Schematic representation of MDH electrophoretic patterns observed in leptocephali samples and genetic interpretation of variability at the $\mathrm{MDH}-1$ and $\mathrm{MDH}-2$ loci. The alleles are indicated by $a, b, c, d$, e in the order of the anodic mobility of the respective homodimer bands (for additional explanations see text) 
Table 1. (a) Observed and, in parentheses, expected MDH-2 genotype distribution and allele frequencies in a sample of Anguilla leptocephali. (b) Expected genotype distribution assuming a genetically heterogeneous sampling (additional explanations see text)

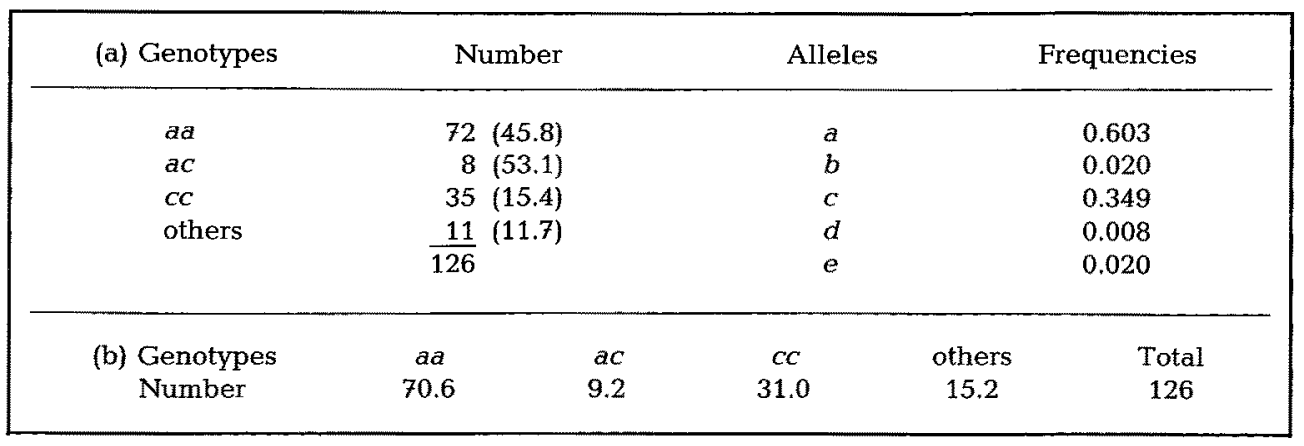

Among the possible factors responsible for this excess, persistent inbreeding can be excluded for obvious reasons; it also seems very unlikely that, in a sample consisting mostly of 0-group larvae aged no more than a few weeks, this excess could originate from strong selection against heterozygotes. Therefore, this distribution most probably results from the sampling together of individuals originating from two distinct populations with an appreciable difference in allele frequencies and separate gene pools (Wahlund effect).

This is consistent with the view that the sample was made up of two different groups of larvae, belonging to the two reproductively isolated gene pools of $A$. anguilla and $A$. rostrata and having the same (or very similar) allele frequencies as reported for the continental populations. The observed genotype distribution is indeed very similar $\left(\chi^{2}{ }_{(3)}=1.86, \mathrm{P}>0.60\right)$ to the expected one (Table $\left.1 \mathrm{~b}\right)$ assuming that the larval sample was composed of specimens belonging to the American and European eel populations at a rate of $61 \%$ and $39 \%$, respectively. The ratio was deduced by considering, in the analysed larval sample, the proportion between the observed number of MDH-2 aa genotypes (common in American eel) and of MDH-2 $\mathrm{CC}$ and other genotypes (common in European eel).

MDH-2 genotypes as a diagnostic character of the leptocephali in Anguilla species

Under this precondition the MDH-2 genotype can also be used in young leptocephali as a species-diagnostic character. This is easy to recognize on board. Indeed, on the basis of the MDH-2 allele frequencies observed in the continental populations, the probability of correct diagnosis of the species is more than 0.998 , calculated by applying the statistics proposed by Ayala \& Powell (1972), if the aa homozygotes are scored as A. rostrata, the heterozygotes showing the "ambiguous" genotype ac are not considered and all other genotypes are scored as $A$. anguilla.

With the use of this parameter it is possible to assume that the analysed sample of 126 leptocephali was composed of $72 \mathrm{~A}$. rostrata (aa genotypes), $46 \mathrm{~A}$. anguilla (cc and other genotypes), and 8 Anguilla of uncertain species attribution (ac genotypes). Of the 5 I-group larvae, 4 were $A$. anguilla and one was of ambiguous genotype. Therefore, the 
121 0-group leptocephali could be subdivided into $72 \mathrm{~A}$. rostrata, $42 \mathrm{~A}$. anguilla and 7 specimens of uncertain attribution.

On the basis of this subdivision, a prevalence of $A$. rostrata larvae is obvious in the latter sample. However, laboratory myomere countings have shown nearly equal num-

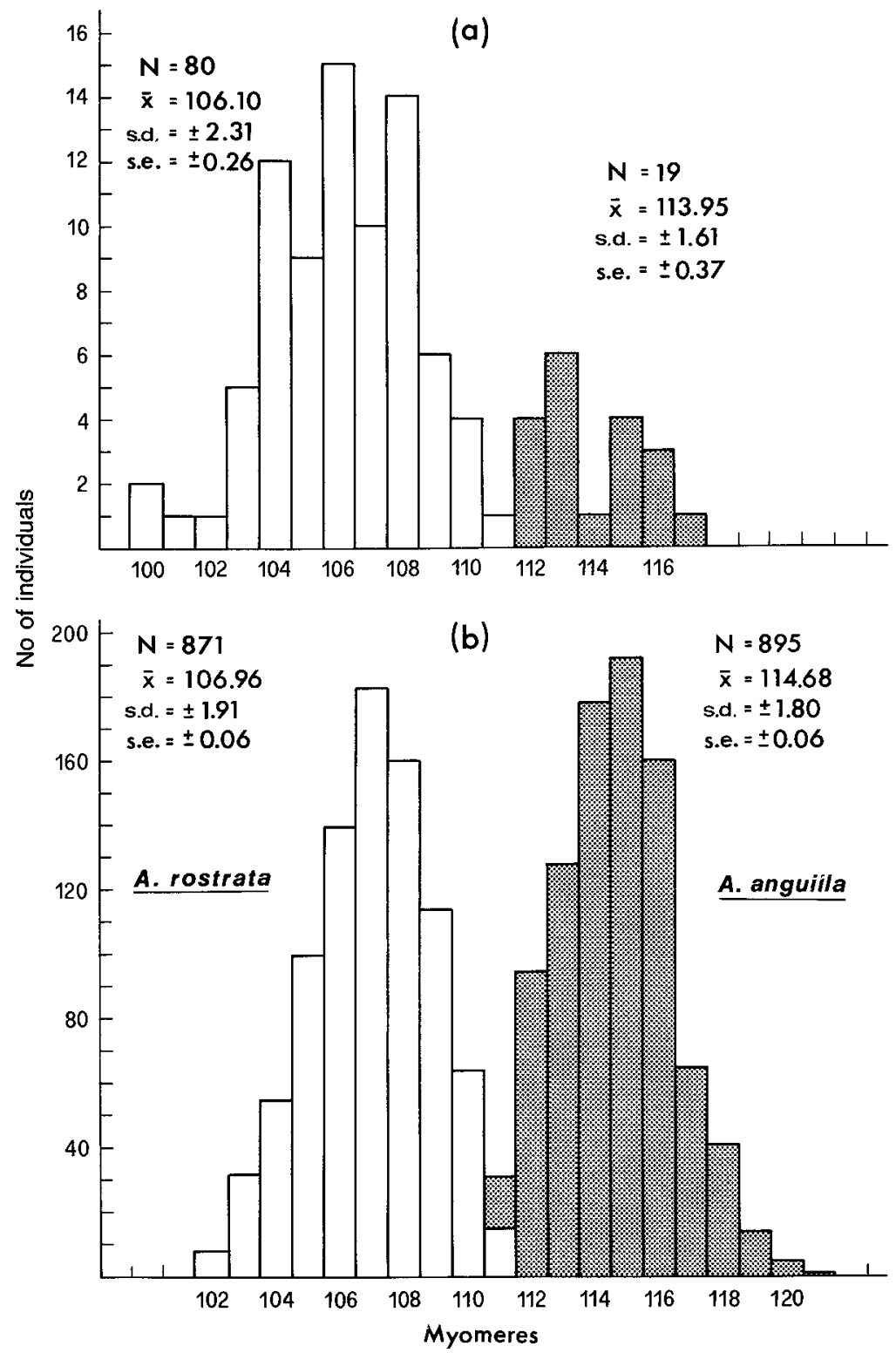

Fig. 4. Distribution of total myomere numbers as observed (a) in the 990 -group leptocephali counted on board before electrophoresis and (b) in the main batch of the 0-group leptocephali by laboratory counts 
bers of individuals of the two species in the main batch of 0 -group leptocephali (Fig. $4 \mathrm{~b}$ ). An explanation of this discordance is that most of the specimens analysed on board were caught west of $65^{\circ} \mathrm{W}$ (see Fig. 1) where, as shown by laboratory countings, A. rostrata larvae were most abundant (Schoth \& Tesch, 1982).

\section{Comparison between electrophoretic and meristic data in 0-group eel larvae}

Of the 1210 -group leptocephali analysed on board by electrophoresis, 105 specimens were subjected to myomere counting beforehand. Total myomere counts could be obtained on 99 individuals; the rest were not counted due to damage or loss of the caudal part. On the basis of their genetic characteristics these 99 individuals were subdivided into $65 \mathrm{~A}$. rostrata, $28 \mathrm{~A}$. anguilla and 6 specimens of uncertain attribution.

Figure $4 \mathrm{a}$ shows the distribution of the total myomere number of the 99 individuals; as expected, a tendency to bimodality is suggested. This suggestion is supported by the corresponding laboratory countings (Fig. 4b) (Schoth, 1982).

Compared with this distribution (Fig. 4b), the one obtained by counting on board (Fig. 4a) gives somewhat lower myomere numbers. In particular, 3 specimens with less than 102 myomeres were counted and both averages are lower in the distribution in Figure $4 \mathrm{a}$. This fact is possibly the consequence of unsuitable counting conditions on board. Because of ship movements, too weak a magnification, and the necessity to treat the fresh larvae quickly - as they are very delicate and decay soon sets in - the counting was rough and not completely reliable. Personal laboratory experience has shown indeed that using weaker magnification and with less routine there is a tendency to count less myomeres, even more so the smaller the larvae are.

In spite of this, however, the numbers of myomeres as discerned in the laboratory and "on board" are comparable. Following a similar criterion for larval sorting as used for the large laboratory sample, based on the observed myomere distribution, 80 of 99 specimens counted on board could be attributed to $A$. rostrata and 19 to $A$. anguilla (Fig. 4a). This result differs to a certain extent from that obtained by using biochemical genetic characters (MDH-2 genotypes) for species identification.

According to the myomere countings, $81 \%$ of the 990 -group leptocephali were designated as $A$. rostrata, and $19 \%$ as $A$. anguilla, whereas according to electrophoretic analysis the values were $70 \%$ and $30 \%$ respectively, the $6 \mathrm{MDH}-2$ ac individuals being proportionately ascribed to the 2 species considered. This difference is illustrated in Figure 5 where the total myomere number distribution is considered for the 0-group leptocephali of different $\mathrm{MDH}-2$ genotype separately.

As regards the $65 \mathrm{MDH}-2$ ad individuals (classified as $A$, rostrata), apart from the 2 specimens $(3.1 \%)$ with less than the reported minimum number of myomeres, all possess from 102 to 112 myomeres and display on the whole a myomere number distribution well in accordance with the expected one for a homogenous sampling of A. rostrata larvae. Taking only $A$. rostrata into consideration, a good diagnostic correspondence seems to exist between electrophoretic and meristic data of the 0-group leptocephali.

The $6 \mathrm{MDH}-2$ ac individuals (of uncertain species attribution) possess 100 to 115 myomeres, 5 larvae having the meristic characteristics of $A$. rostrata. This is a species ratio not much different from the expected one of about $5: 2$, considering in the sample of 

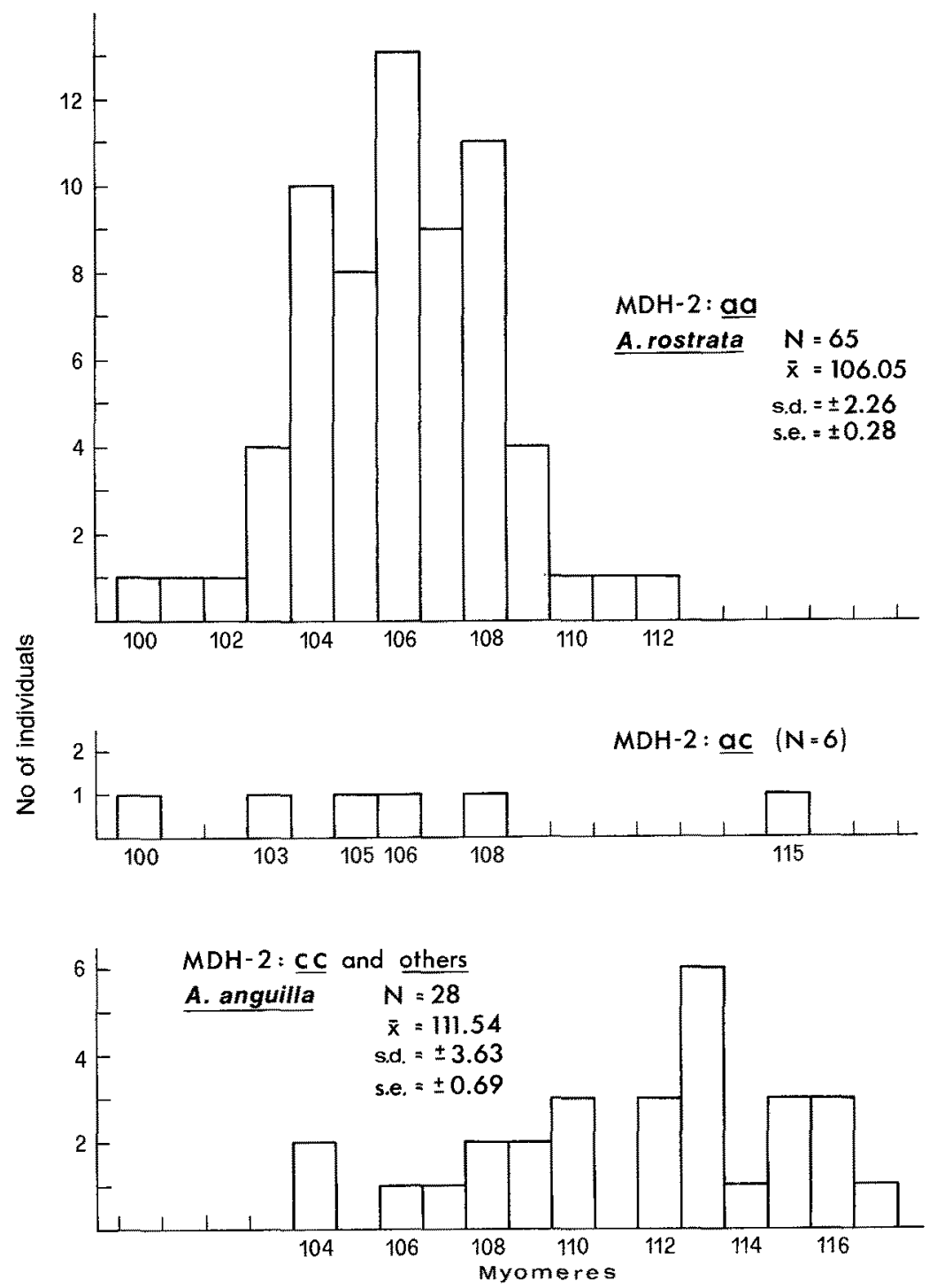

Fig. 5. Distribution of the total myomere number in 0-group leptocephali of different $\mathrm{MDH}-2$ genotypes. Individuals of MDH-2 aa genotype are scored as $A$. rostrata, MDH-2 acindividuals are not classified and those of $\mathrm{MDH}-2$ cc genotypes and others are scored as $A$. anguilla

99 specimens the proportion of larvae with MDH-2 genotype of American and European eel, respectively.

Of particular interest, however, is the myomere number distribution of the 28 leptocephali with typical MDH-2 genotypes (cc and others) of $A$. anguilla. This distribution appears to be irregular and remarkably shifted towards lower myomere numbers than expected for a homogeneous sampling of $A$. anguilla larvae. The number of myomeres ranges from 104 to 117 ; and the average of $111.5 \pm 0.7$ is much lower than that 
observed in the large sample where counting took place in the laboratory (Fig. $4 \mathrm{~b}) .11$ out of 28 specimens (= about $39 \%$ ) show a myomere number ranging from 104 to 110 (average $=107.7 \pm 0.7$ ). On the basis of these data one might think that it is unreliable to use the number of myomeres to determine the specific status of young Anguilla larvae, as this does not always accord with the genetic character as deduced by MDH electrophoretic patterns; especially in the case of the leptocephali displaying the typical MDH-2 genotype of $A$. anguilla, having at the same time, in many cases, the same number of myomeres as $A$. rostrata.

But we must not forget the consequences resulting from bad counting conditions on board nor the fact that the 0-group leptocephali of $A$. anguilla with their higher mean number of myomeres were, on the average, shorter than those of $A$. rostrata.

Concerning the 99 specimens in which complete myomere countings were carried out, we obtained the following results:

$\overline{\mathrm{x}}=17.7 \pm 0.5 \mathrm{~mm}$ in the $65 \mathrm{MDH}-2$ aa larvae (A. rostrata),

$\overline{\mathrm{x}}=19.1 \pm 0.9 \mathrm{~mm}$ in the $6 \mathrm{MDH}-2$ ac larvae (uncertain Anguilla species),

$\overline{\mathrm{x}}=15.8 \pm 0.5 \mathrm{~mm}$ in the $28 \mathrm{MDH}-2 \mathrm{cc}$ and other genotype larvae (A. anguilla)

The concomitance of these facts could possibly have been, at least for the larger part, the cause of the above observed disagreement. It is possible that myomere counts on board and particularly those concerning $A$. anguilla larvae were partially wrong.

\section{DISCUSSION}

The study of the MDH-2 genotype distribution by electrophoretic analysis in a sample of young Anguilla leptocephali (predominantly from the 0-group) has revealed the presence of two different and genetically isolated groups of larvae in the spawning area of the Sargasso Sea. As demonstrated above, the establishment of a clear-cut genetic difference between two groups of young leptocephali in the Sargasso Sea definitively confirms Schmidt's theory of the existence of two distinct Atlantic Anguilla species.

In view of the genetic difference between the two larval groups, observed at the $\mathrm{MDH}$-locus, this character may provide an alternative diagnostic aid for the identification of the two species even at a very early larval stage.

On the basis of MDH-2 allozyme patterns, more than $93 \%$ of the analysed leptocephali could be divided, with a very small probability of error $(\mathrm{P}<0.002)$, into the two Anguilla species; the rest had genotypes of uncertain species attribution. Comparison of allele frequencies at other enzyme loci (Comparini \& Rodinó, 1980) has shown differences between the two larval groups, thus supporting their different species character.

Classical species identification depends on the total number of myomeres or vertebrae; but the hereditability of meristic characters has never been studied in eels, because breeding under controlled conditions is still impossible. Therefore, changes in the individual expression of these characters due to changes of environmental or agedependent factors cannot completely be excluded a priori.

On the basis of our analysis of 0-group eel larvae on board, species identification by myomere counts does not fully accord with that presented by genetic characteristics. In fact, of the 93 leptocephali assigned to each of the two species according to MDH-2 
genotypes (see Fig. 5), 12 had a total myomere number that is in disagreement with the preceding attribution to a certain species. As mentioned above, this disagreement concerns particularly the individuals of $A$. anguilla genotype. We have pointed out, however, the unreliability of myomere countings taken on board, especially regarding the leptocephali genetically assigned to $A$, anguilla. On future expeditions it would be advantageous, therefore, to take more reliable counts of myomeres before electrophoresis of larvae is carried out on board and to examine representative subsamples of Anguilla larvae from every haul.

Acknowledgements. We wish to thank Dr. F.-W. Tesch for giving this opportunity to participate in the cruise and for his helpful suggestions during the preparation of the manuscript. We are also grateful to the scientific staff and to the "Anton Dohrn" crew for their help and friendliness as well as to Mr. C. Friso (Padua) for his assistance in the preparation of the illustrations. Furthermore, our grateful acknowledgements are due to Prof. E. Rodinò for his helpful suggestions during the preparation of this paper.

\section{LITERATURE CITED}

Allendorf, F. W. \& Utter, F. M., 1979. Population genetics. In: Fish physiology. Ed. by W. S. Hoar, D. J. Randall \& J. R. Brett. Acad. Press, New York, 3, 407-454.

Avise, J. C., 1975. Systematic value of electrophoretic data. - Syst. Zool. 23, 465-481.

Ayala, F. J. \& Powell, J. R., 1972. Allozymes as diagnostic characters of sibling species of Drosophila. - Proc. ntn. Acad. Sci. U.S.A. 69, 1094-1096.

Ayala, F. J. \& Valentine, J. W., 1978. Genetic variation and resource stability in marine invertebrates. In: Marine organism: genetics, ecology and evolution. Ed. by. B. Battaglia \& J. A. Beardmore. Plenum Press, New York, 23-51.

Brewer, G. J., 1970. An introduction to isoenzyme techniques. Acad. Press, London, $160 \mathrm{pp}$.

Comparini, A., Rizzotti, M. Nardella, M. \& Rodinó, E., 1975. Ricerche elettroforetiche sulla variabilità genetica di Anguilla anguilla. - Boll. Zool. 42, 283-288.

Comparini, A. \& Rodinó, E., 1980. Electrophoretic evidence for two species of Anguilla leptocephali in the Sargasso Sea. - Nature, Lond. 287, 435-437.

Jamieson, A. \& Turner, R. J. 1980. Muscle protein differences in two eels Anguilla anguilla (Linnaeus) and Anguilla rostrata (Le Sueur). - Biol. J. Linn. Soc. 13, 41-45.

Koehn, R. K. \& Williams, G. C., 1978. Genetic differentiation without isolation in the American eel, Anguilla rostrata. II. Temporal stability of geographic patterns. - Evolution 32, 624-637.

Ligny, W. de (Ed.), 1971. Special meeting on the biochemical and serological identification of fish stocks. Dublin 1969. - Rapp. P. - v. Réun. Cons. int. Expl. Mer, 161, 1-179.

Ligny, W. de, 1972. Blood groups and biochemical polymorphisms in fish. In: Proceedings of $12^{\text {th }}$ European Conference on Animal Blood Groups and Biochemical Polymorphism, Budapest, 1970. Ed. by. G. Kovacs \& M. Papp. Junk, The Hague, 55-65.

Ligny, W. de \& Pantelouris, E. M., 1973. Origin of the European eel, - Nature, Lond. 246, 518-519.

Rodinó, E. \& Comparini, A., 1978a. Genetic variability in the European eel Anguilla anguilla L. In: Marine organism: genetics, ecology and evolution. Ed. by B. Battaglia \& J. A. Beardmore. Plenum Press, New York, 389-424.

Rodinó, E. \& Comparini, A., 1978b. Biochemical polimorphism in teleosts. The eel problem. - Boll. Zoll. 45 (Suppl. 2), 47-61.

Rollinson, D., 1980. Enzymes as a taxonomic tool: a zoologist's view. In: Chemosystematics: principles and practice. Ed. by. F. A. Bisby, J. G. Vaughan \& C. A. Wright. Acad. Press, London, $123-146$.

Schmidt, J., 1932. Danish eel investigations during 25 years (1905-1930). Nordisk Forlag, Kobenhavn, $16 \mathrm{pp}$.

Schoth, M., 1982. Taxonomic studies on the 0-group eel larvae (Anguilla sp.) caught in the Sargasso Sea in 1979. - Helgoländer Meeresunters. 35, 279-287. 
Schoth, M. \& Tesch, F..W., 1982. Spatial distribution of the 0-group eel larvae (Anguilla sp.) 1979 in the Sargasso Sea. - Helgoländer Meeresunters. 35, 309-320.

Sick, K, Bahn, E., Frydenberg, O., Nielsen, J. T.\& Wettstein, D. von, 1967. Haemoglobin polymorphism of the American freshwater eel Anguilla. - Nature, Lond. 214, 1141-1142.

Smith, D. G., 1979. Guide to the leptocephali (Elopiformes, Anguilliformes and Notacanthiformes). - NOAA tech. Rep., NMFS Circ. 424, 1-39. (Bull U.S. Fish Commn 21, 1901, 81-92).

Tesch, F.-W., 1982. The Sargasso Sea Eel Expedition 1979. - Helgolander Meeresunters. 35, 263-277.

Tesch, F.-W., Kracht, R, Schoth, M, Smith, D. G. \& Wegner, G, 1979. Report on the eel expedition of F. R. V. "Anton Dohrn" and R. C. "Friedrich Heincke" to the Sargasso Sea 1979. - C. M./ICES/ $M 6$.

Tucker, D. W, 1959. A new solution to the Atlantic eel problem. - Nature, Lond. 183, 495-501.

Utter, F. M., Hodgings, H. O. \& Allendorf, F. W., 1974. Biochemical genetic studies of fishes: potentialities and limitations. In: Biochemical and biophysical perspectives in marine biology. Ed. by D. C. Malins \& J. R. Sargent. Acad. Press, 1, 213-238.

Williams, G. C., Koehn, R. K. \& Mitton, J. B., 1973. Genetic differentiation without isolation in the Americal eel, Anguilla rostrata. - Evolution 27, 192-204. 